\title{
Photoadaptation in marine phytoplankton: variations in ribulose 1,5-bisphosphate activity
}

\author{
Richard B. Rivkin \\ Horn Point Environmental Laboratories, University of Maryland, Cambridge, Maryland 21613, USA
}

\begin{abstract}
The rates of photosynthesis and the activity of ribulose 1,5-bisphosphate carboxylase (RuBPCase) were concurrently measured for phytoplankton in laboratory cultures and isolated from natural populations. Both photosynthetic capacity (Pmax) and RuBPCase activity were greater for phytoplankton adapted to high than low irradiances. Using single-species radioisotope techniques, the irradiance-dependent rates of photosynthesis and the RuBPCase activity of Ditylum brightwellii and Ceratium lineatum, 2 common coastal phytoplankton, were measured at a Chesapeake Bay, USA, plume front. The photosynthetic characteristics and RuBPCase were clearly dependent on the photic regime. The species-specific Pmax and RuBPCase activity was similar for phytoplankton isolated throughout the water column on the well-mixed, oceanic side of the front and within the surface mixedlayer on the stratified, estuarine side of the front. In contrast, these photosynthetic parameters were significantly lower for the same species isolated from below the pycnocline upstream of the frontal interface. Changes in RuBPCase correlated $(\mathrm{p}=0.01)$ with those in Pmax; for light-limited and -saturated phytoplankton in culture and from natural populations, the relationship was linear and significant. The coordinate pairs of Pmax and RuBPCase from all the laboratory and field, i.e. all stations and depths, experiments were fit to the linear regression $(n=84)$ RuBPCase $=-1.686( \pm 7.675)+0.677$ $\operatorname{Pmax}( \pm 0.043) ; r^{2}=0.872$. Variations in Pmax are commonly used to describe the photoadaptations of phytoplankton from different photic regimes. The results of this study suggest that the temporal and spatial variations in RuBPCase may be a useful photoadaptive parameter for phytoplankton in nature.
\end{abstract}

\section{INTRODUCTION}

Ribulose 1,5-bisphosphate carboxylase (RuBPCase; E.C. 4.1.1.39) is ubiquitous in autotrophic organisms; it comprises 20 to $40 \%$ of total plant protein and is the most abundant enzyme in nature. RuBPCase catalyzes the reduction of $\mathrm{CO}_{2}$ during the Calvin cycle. Thus, its activity and concentration governs the maximum rate of light-dependent inorganic carbon assimilation. The factors which regulate this enzyme would influence the rates of carbon uptake and ultimately growth. The genetics, structure and regulation of RuBPCase has been studied extensively in higher plants (e.g. Lorimer 1981. Yoeh et al. 1981, Miziorko \& Lorimer 1983, Akazawa et al. 1984, Kobza \& Seemann 1988), but not in microalgae (Estep et al. 1978. Appleby et al. 1980, Hobson et al. 1985, Plumley et al. 1986, Newman \& Cattolico 1987). Despite the obvious biochemical and physiological importance of RuBPCase, there have been surprisingly few systematic studies on the relationships between RuBPCase, or the $\beta$-carboxylating enzymes, phosphoenolpyruvate carboxylase (PEPCase; E.C. 4.1.1.31) and phosphoenolpyruvate carboxykinase (PEPCKase; E.C. 4.1.1.49), and the more commonly measured photosynthetic or growth characteristics of microalgae (Hellebust \& Terborgh 1967, Holdsworth \& Colbeck 1976, Beardall \& Morris 1978, Glover \& Morris 1979, Smith et al. 1985). In this study, the relationship between photosynthesis and RuBPCase was examined for several marine phytoplankton from laboratory cultures and from natural populations.

Previous laboratory studies suggest that the rate of light-saturated photosynthesis, i.e. Pmax, and the activity of RuBPCase can co-vary and that both may be influenced by temperature, irradiance, photoperiod and ambient nutrient concentrations (Beardall \& Morris 1978, Harris 1978, Senger \& Fleischhacker 1978, Morris 1981, Li \& Morris 1982, Hobson et al. 1985, DescolasGros \& Billy 1987, Mortain-Bertrand et al. 1987, Guy et al. 1989 and others). However, within natural phytoplankton populations Pmax and RuBPCase are not usually correlated (Glover \& Morris 1979, Smith et al. 1983, 
Li et al. 1984, Smith \& Platt 1985, Mortain-Bertrand et al. 1987). The absence of a significant relationship may reflect incorporation of ${ }^{14} \mathrm{CO}_{2}$ by metabolic pathways other than the Calvin cycle (Glover et al. 1975, Beardall et al. 1976, Holdsworth \& Bruck 1977, Mukerji et al. 1978, Mortain-Bertrand et al. 1987, Mortain-Bertrand 1988 and references cited therein). Alternatively, since a phytoplankton community contains many species, each with potentially distinct rates and patterns of photosynthesis, distinct kinetics of photoadaptation to the ambient light, nutrient or temperature regimes and distinct ratios of carboxylating enzymes, the response of the intact community may obscure significant physiological relationships of the individual component species. In this study, single species techniques were used to examine the relationship between photosynthesis and RuBPCase for net-phytoplankton from natural populations.

The rates of phytoplankton production and growth in the ocean are influenced by the turbulent motion within the surface mixed layer (Harris 1980, Lewis et al. $1984 \mathrm{~b})$. Rates of vertical mixing have been estimated by concurrently measuring the vertical distribution of several irradiance-dependent photosynthetic characteristics, i.e. photosynthesis-irradiance curve parameters, fluorescence yield etc., for phytoplankton within the mixed layer (Falkowski 1983, Lewis et al. 1984a, Cullen \& Lewis 1988). Evaluating the consequences of vertical mixing on the rates of photoadaptation requires the precise measurement of the rates of change of the photoadaptive parameters and an understanding of how phytoplankton integrate their variable photic environment. One of the objectives of this paper was to determine whether RuBPCase activity is a useful photoadaptive parameter for phytoplankton in nature. This was done by (1) concurrently measuring the RuBPCase activity and irradiance-dependent rates of carbon uptake for cultures of phytoplankton adapted to growthlimiting and saturating irradiances; (2) developing the protocol to routinely measure the activity of RuBPCase in individual species of net-plankton isolated from natural phytoplankton populations; and (3) measuring the photosynthesis-irractiance (P-I) relationship and the RuBPCase activity for individual phytoplankton species isolated from distinct photic regimes. The field work was carried out at a Chesapeake Bay plume front. Frontal regions are often characterized by elevated planktonic biomass and production (Pingree et al. 1975). The same phytoplankton species frequently occur on the well-mixed and stratified sides of a front (Holligan et al. 1984), therefore a range of photoadaptations may be found over relatively small spatial scales. Using high resolution single-species radioisotope techniques (Rivkin \& Seliger 1981, Rivkin \& Voytek 1985, 1986, Rivkin \& Lessard 1986), a signifi- cant ( $p=0.01$ ) linear relationship between RuBPCase and photosynthetic capacity was found for phytoplankton in laboratory cultures and natural populations. These results suggest that temporal and spatial variations in RuBPCase may be useful to describe the photoadaptations of phytoplankton in nature.

\section{METHODS}

Culture. Unialgal cultures of Skeletonema costatum (Clone SC-1), Ditylum brightwellii (Clone L-1332), Duanliella tertiolecta (Clone DUN) and Protogonyaulax tamarensis (Clone 429) were grown in one-half strength ' $F$ ' $(\mathrm{F} / 2)$-enriched $30 \%$ salinity seawater (Guillard \& Ryther 1962) at $15 \pm 1{ }^{\circ} \mathrm{C}$ with a $12 \mathrm{~h}$ $\mathrm{L}: 12 \mathrm{~h} \mathrm{D}$ photoperiod of fluorescent illumination. For the diatoms $S$. costatum and $D$. brightwellii, the seawater medium was supplemented with $75 \mu \mathrm{M}$ silicon. Batch cultures were inoculated to a low initial cell density and irradiances were adjusted by covering culture flasks with neutral density filters. Cultures were preconditioned to their incubation conditions for at least 1 wk prior to experiments. Routine cell counts were done with a haemocytometer ( $S$. costatum and $D$. tertiolecta) or Palmer-Maloney (D. brightwellii and $P$. tamarensis) counting chamber. Cell division rates (doublings $\mathrm{d}^{-1}$ ) were calculated from the least squares fit of the relationship between the logarithm of the cell abundance and time in days.

The photosynthetic characteristics, chlorophyll a (Chl a), and activity of RuBPCase were determined for exponentially growing phytoplankton adapted to several growth limiting and saturating irradiances. One of the objectives of these experiments was to develop the protocol to routinely measure the RuBPCase of individual species of phytoplankton isolated from natural assemblages. Thus, the RuBPCase activity was compared for the same species of phytoplankton collected and assayed by the traditional method of filtering large numbers of cells from suspension with that of isolating cells individually (Rivkin \& Seliger 1981, Rivkin 1985)

Analytical procedures. Chl a was assayed ( $\mathrm{n}=3$ or 4) fluorometrically by filtering the cell suspension (in the laboratory) or particulate material (in the field) onto Whatman GF/F glass fiber filters as previously described (Rivkin et al. 1982). The fluorometer was calibrated with pure $\mathrm{Chl}$ a.

The P-I relationship was determined for algae grown at several growth-rate-limiting and saturating irradiances. Triplicate subsamples inoculated with $\mathrm{NaH}^{14} \mathrm{CO}_{3}$ to a final activity of ca $0.1 \mu \mathrm{Ci} \mathrm{m} l^{-1}$ were incubated at 9 irradiances ( 2 to $400 \mu \mathrm{E} \mathrm{m}^{-2} \mathrm{~s}^{-1}$ ) for ca $1 \mathrm{~h}$. Experiments were terminated by filtering cells onto $25 \mathrm{~mm}$ diameter Whatman GF/F filters. The P-I curves were fit to a 
hyperbolic tangent equation (Jassby \& Platt 1976) and the parameters of maximum photosynthetic capacity (Pmax) and slope of the light limited region of the P-I curve $(\alpha)$ were determined as previously described (Rivkin \& Putt 1987).

RuBPCase activity was measured by a modification of the assay described by Glover \& Morris (1979). Filters, or cells isolated by micromanipulation, were placed into $7 \mathrm{ml}$ glass liquid scintillation vials with $0.3 \mathrm{ml}$ of $1 \%$ Triton $100 \mathrm{X}$ and immediately frozen $\left(-20^{\circ} \mathrm{C}\right)$ until RuBPCase was assayed. The vials were thawed at $15^{\circ} \mathrm{C}$, i.e, the growth temperature, and $1.0 \mathrm{ml}$ of the assay mixture containing $70 \mathrm{mmol}$ Tris$\mathrm{HCl}(\mathrm{pH} 8.0), 15 \mathrm{mmol}$ reduced glutathione, $40 \mathrm{mmol}$ $\mathrm{NaHCO}_{3}$ and $25 \mathrm{mmol} \mathrm{MgCl}_{2}$ was added. RuBPCase was activated (Jensen \& Sicher 1978) by incubating the filters or cells in the assay mixture for 15 to $20 \mathrm{~min}$ and the reaction was initiated by adding $100 \mu \mathrm{l}$ of $13 \mathrm{mmol}$ ribulose 1,5-bisphosphate (RuBP, sodium salt) and $100 \mu \mathrm{l}$ of $\mathrm{H}^{14} \mathrm{CO}_{3}^{-}\left(2\right.$ to $2.5 \mu \mathrm{Ci} ; 50$ to $55 \mathrm{mCi} \mathrm{mmol}^{-1}$ ). Replicate vials ( $\mathrm{n}=3$ for filtered samples and $\mathrm{n}=5$ for isolated cells), 2 reagent blanks (without RuBP) and a zero time blank were assayed for RuBPCase activity. After incubating for 1 to $1.5 \mathrm{~h}$ at $15^{\circ} \mathrm{C}$, the reaction was terminated by adding $2 \mathrm{ml}$ of acidified methanol (1:10 acetic acid:methanol) and evaporating to dryness at $45^{\circ} \mathrm{C}$. To ensure that all the $\mathrm{H}^{14} \mathrm{CO}_{3}^{-}$was converted to ${ }^{14} \mathrm{CO}_{2}$, the residue was extracted a second time in $2 \mathrm{ml}$ of the acidified methanol. This second extraction was required since the net incorporation of ${ }^{14} \mathrm{C}$ into the acid stable fraction by isolated cells was typically low $(\leq 200 \mathrm{dpm})$. The dried residue was rehydrated in $0.3 \mathrm{ml}$ deionized water prior to ${ }^{14} \mathrm{C}$ counting. This assay measures the RuBPCase activity, not enzyme concentration (Hobson et al. 1985. Plumley et al. 1986) thus, changes in enzyme activity may reflect changes in in vivo enzyme activation or de novo enzyme synthesis.

Field studies. The irradiance-dependent rates of photosynthesis and the RuBPCase activity of individual species of phytoplankton in the southern Chesapeake Bay and adjacent coastal waters were measured during cruise Corsair 4 aboard the RV 'Cape Hatteras' in March 1984. The horizontal and vertical water density structure was determined using an interoceans conductivity-temperature probe. During transects seawater was pumped from a depth of $1 \mathrm{~m}$; salinity and temperature were continuously recorded and Chl a was measured at ca $1 \mathrm{~km}$ intervals.

During experiments, downwelling irradiances (photosynthetically active radiation; PAR 400 to $700 \mathrm{~nm}$ ) were measured with a quantum photometer (Li-Cor Model LI-185) equipped with a submarine cosine sensor (Model LI-192). Water samples for vertical profiles and experiments were collected between 10:00 and 12:00 h. Chl a was analyzed as described above. Phytoplankton were collected at discrete depths with $5 \mathrm{l}$ Niskin bottles or by towing a double closing $0.5 \mathrm{~m}$ diameter, $20 \mu \mathrm{m}$ aperture plankton net. Within $0.5 \mathrm{~h}$ of collection, plankton samples were subdivided: one subsample was used to determine the speciesspecific P-I relationship for representative net-plankton. Aliquots were inoculated with 0.8 to $1.0 \mu \mathrm{Ci} \mathrm{ml} \mathrm{ml}^{-1}$ $\mathrm{NaH}^{14} \mathrm{CO}_{3}$ (final activity) and incubated for 1 to $2 \mathrm{~h}$ in flowing seawater $\left(5.5\right.$ to $\left.6.5^{\circ} \mathrm{C}\right)$ at a range of irradiances (10 to $850 \mu \mathrm{E} \mathrm{m} \mathrm{m}^{-2} \mathrm{~s}^{-1}$ ). Experiments were terminated, samples were processed and cells isolated as previously described (Rivkin \& Seliger 1981, Rivkin et al. 1982, Rivkin 1985). Using these techniques, ca 1000 algal cells $\mathrm{h}^{-1}$ can be sorted. For each species, 8 to 10 replicate vials with 3 to 30 cells vial $^{-1}$ were typically isolated. Phytoplankton were isolated from the second subsample and their species-specific RuBPCase activity was determined. For each species, 7 replicate ( $\mathrm{n}=5$ plus 2 reagent blanks) vials with 25 to 35 cells vial $^{-1}$ were isolated: the RuBPCase assay was identical to that described above except that the samples were incubated for 1 h at ambient seawater temperatures.

Radiation counting. Radioactivity was counted using a Packard Tri-Carb (Model $460 \mathrm{C}$ ) liquid scintillation spectrometer with Biofluor as the scintillant. All counts were corrected for quench by the external standards method and for background radiation.

\section{RESULTS}

\section{Laboratory experiments}

The growth-rate-limiting and saturating irradiances (Table 1) were selected based upon cell divisionirradiance curves previously determined for each alga (Rivkin unpubl.). The Pmax and RuBPCase activity, and the cell division rate was higher and $\mathrm{Chl}$ a cell-1 was lower for phytoplankton adapted to high than low irradiances (Table 1). During exponential growth the activity of RuBPCase was ca 60 to $70 \%$ of the measured Pmax (Tables 1 \& 2). There were significant $(p=0.01)$ and linear relationships between Pmax and RuBPCase activity for each of the species studied (Table 2). When the coordinate pairs of Pmax and RuBPCase for the 4 species, representing 3 taxonomic classes, were combined the relationship between Pmax and RuBPCase activity (Eqn 1) was linear and significant $(p=0.01)$ :

RuBPCase $=0.930( \pm 3.728)+0.611 \cdot \operatorname{Pmax}( \pm 0.163) ;$
$\mathrm{r}^{2}=0.918$.

The values in parentheses are the $95 \%$ confidence intervals $(n=36)$. The regression coefficients for 4 species of phytoplankton in culture were not significantly $(p=0.05)$ different from one another (Table 2 ) or 
Table 1. Comparison of maximum photosynthetic capacity ( $\mathrm{Pmax} ; \mathrm{pg} \mathrm{C}$ cell ${ }^{-1} \mathrm{~h}^{-1}$ ), ribulose 1,5-bisphosphate carboxylase activity (RuBPCase; pg C cell ${ }^{-1} \mathrm{~h}^{-1}$ ), chlorophyll a (Chl a; $\mathrm{pg} \mathrm{cell}{ }^{-1}$ ) and cell division rate (doublings $\mathrm{d}^{-1}$ ) of 4 species of phytoplankton adapted to growth-rate-saturating and limiting irradiances $\left(\mu \mathrm{E} \mathrm{m}^{-2} \mathrm{~s}^{-1}\right)$. Values in parentheses are standard deviations; $n=3$ for Pmax, RuBPCase and division rate $n=4$ for Chl a

\begin{tabular}{|c|c|c|c|c|}
\hline Growth irradiance & $P \max$ & RuBPCase & Chl a & Division rate \\
\hline \multicolumn{5}{|c|}{ Skeletonema costatum } \\
\hline $150^{\mathrm{a}}$ & $1.23(0.12)$ & $0.86(0.18)$ & $0.27(0.03)$ & $0.92(0.11)$ \\
\hline $40^{b}$ & $0.65(0.07)$ & $0.43(0.17)$ & $0.45(0.04)$ & $0.41(0.06)$ \\
\hline $15^{\mathrm{b}}$ & $0.45(0.02)$ & $0.29(0.10)$ & $0.61(0.09)$ & $0.12(0.02)$ \\
\hline \multicolumn{5}{|l|}{ Ditylum brightwellii } \\
\hline $220^{a}$ & $215(18)$ & $124(22)$ & $23(3.4)$ & $0.82(0.11)$ \\
\hline $100^{\circ}$ & $102(9.3)$ & $58(11)$ & $54(4.1)$ & $0.41(0.09)$ \\
\hline $45^{\mathrm{b}}$ & $47(4.3)$ & $28\{2.0\}$ & $66(6.1)$ & $0.22(0.06)$ \\
\hline \multicolumn{5}{|c|}{ Dunaliella tertiolecta } \\
\hline $230^{a}$ & $1.95(0.23)$ & $0.91(0.20)$ & $0.41(0.07)$ & $0.74(0.11)$ \\
\hline $85^{\mathrm{b}}$ & $0.83(0.09)$ & $0.44(0.09)$ & $0.73(0.12)$ & $0.41(0.03)$ \\
\hline $20^{\mathrm{b}}$ & $0.32(0.06)$ & $0.16(0.04)$ & $1.21(0.38)$ & $0.20(0.07)$ \\
\hline \multicolumn{5}{|c|}{ Protogonyaulax tamarensis } \\
\hline $260^{\alpha}$ & $155(13)$ & $106(14)$ & $11(1.3)$ & $0.57(0.06)$ \\
\hline $75^{b}$ & $92(11)$ & $63(10)$ & $26(3.1)$ & $0.41(0.06)$ \\
\hline $35^{b}$ & $44(5.5)$ & $30(6.0)$ & $42(3.8)$ & $0.21(0.02)$ \\
\hline \multicolumn{5}{|c|}{${ }^{a}$ Growth-rate-saturating irradiance } \\
\hline
\end{tabular}

from that in Eqn 1. Furthermore, the ordinal intercepts were not significantly $(\mathrm{p}=0.05)$ different from zero (Table 2, Eqn 1)

There was no significant difference $(p=0.05$; Student's t-test) in the Pmax, RuBPCase-activity or the RuBPCase: Pmax ratio for phytoplankton filtered from suspension compared with those individually isolated (Table 3). Hence, this assay procedure could be used to measure the activity of RuBPCase for individual species of phytoplankton from natural assemblages. The minimum detection limit of the single species ${ }^{14} \mathrm{C}$ incorporation technique is a net counting rate of 1 to $2 \mathrm{dpm}$ or about ca 0.5 to $1 \mathrm{pg} \mathrm{C}$ at $30 \%$ salinity (Rivkin
\& Seliger 1981, Rivkin 1985). The lower limits of the technique are governed by the volume specific ${ }^{14} \mathrm{C}$ activity, e.g. $1.0 \mu \mathrm{Ci} \mathrm{ml} \mathrm{ml}^{-1}$, 'blank' background radiation, e.g. 2 to $4 \mathrm{dpm}$, and scintillation counting time, e.g. $30 \mathrm{~min}$ sample ${ }^{-1}$. Since the RuBPCase activity was

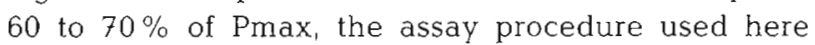
could detect enzyme activities of 1 to $2 \mathrm{pg} \mathrm{C}$ within an individual cell. The sensitivity could be significantly increased by using $>2.0 \mu \mathrm{Ci}{ }^{14} \mathrm{C} \mathrm{ml}^{-1}$ or isolating several cells vial ${ }^{-1}$. For example, during these experiments 25 cells were usually isolated into each vial, hence, the detection limit for RuBPCase activity was ca $0.04 \mathrm{pg} \mathrm{C}$ cell ${ }^{-1}$

Table 2. Summary of regression statistics for the linear relations between maximum photosynthetic capacity (Pmax) and ribulose 1.5-bisphosphate carboxylase (RuBPCase) activity for the 4 phytoplankton species grown at growth-rate-saturating and -limiting irradiances in laboratory culture and for the 2 species isolated from natural populations at the mouth of the Chesapeake Bay. Values in parentheses are $95 \%$ confidence intervals; n: no. paired measurements of Pmax and RuBPCase

\begin{tabular}{|c|c|c|c|c|}
\hline Species & Intercept & Regression coefficient & $r^{2}$ & $\mathrm{n}$ \\
\hline \multicolumn{5}{|l|}{ Laboratory cultures } \\
\hline Skeletonema costatum & $-0.046(0.071)$ & $0.632(0.115)$ & 0.996 & 9 \\
\hline Ditylum brightwellii & $2.09 \quad(3.51)$ & $0.616(0.028)$ & 0.979 & 9 \\
\hline Dunaliella tertiolecta & $0.034(0.083)$ & $0.554(0.196)$ & 0.919 & 9 \\
\hline Protogonyaulax tamarensis & $0.707(0.541)$ & $0.627(0.076)$ & 0.955 & 9 \\
\hline \multicolumn{5}{|l|}{ Field populations } \\
\hline Ditylum brightwellii & $-2.62 \quad(8.31)$ & $0.711(0.151)$ & 0.943 & 24 \\
\hline Ceratium lineatum & $-3.54 \quad(6.54)$ & $0.763(0.243)$ & 0.679 & 24 \\
\hline
\end{tabular}


Table 3. Comparison of cell-specific photosynthetic capacity (Pmax; pg C cell ${ }^{-1} \mathrm{~h}^{-1}$ ) and ribulose 1,5-bisphosphate carboxylase activity (RuBPCase; pg C cell $\mathrm{h}^{-1}$ ) calculated from filter-retained (Retained) activity and by isolating cells (Isolated). Growth irradiance in $\mu \mathrm{E} \mathrm{m}^{-2} \mathrm{~s}^{-1}$ Values in parentheses are standard deviations; $\mathrm{n}=3$ for filter-retained samples and 8 to 10 for isolated cells; ND: not determined

\begin{tabular}{|c|c|c|c|c|}
\hline \multirow[t]{2}{*}{ Growth irradiance } & \multicolumn{2}{|c|}{ Pmax } & \multicolumn{2}{|c|}{ RuBPCase } \\
\hline & Retained & Isolated & Retained & Isolated \\
\hline \multicolumn{5}{|l|}{ Ditylum brightwellii } \\
\hline $220^{\circ}$ & $215(18)$ & $201(10)$ & $124(22)$ & $118(28)$ \\
\hline $100^{b}$ & $102(9.3)$ & $98(11)$ & $58(11)$ & $62(9.0)$ \\
\hline $45^{b}$ & $47(4.3)$ & $48(9.1)$ & $28(2.0)$ & $31(4.1)$ \\
\hline \multicolumn{5}{|l|}{ Dunaliella tertiolecta } \\
\hline $230^{\mathrm{a}}$ & $1.95(0.23)$ & $1.84(0.31)$ & $0.91(0.20)$ & $1.10(0.22)$ \\
\hline $85^{b}$ & $0.83(0.09)$ & $0.92(0.11)$ & $0.44(0.09)$ & $0.35(0.05)$ \\
\hline $20^{\mathrm{b}}$ & $0.32(0.06)$ & ND & $0.16(0.04)$ & ND \\
\hline \multicolumn{5}{|c|}{ Protogonyaulax tamarensis } \\
\hline $260^{\mathrm{a}}$ & $155(13)$ & $151(18)$ & $106(14)$ & $101(21)$ \\
\hline $75^{\mathrm{b}}$ & $92(11)$ & $86(9.7)$ & $63(10)$ & $51(8.5)$ \\
\hline $35^{\mathrm{b}}$ & $44(5.5)$ & $39(4.6)$ & $30(6.0)$ & $36(3.1)$ \\
\hline $\begin{array}{l}{ }^{2} \text { Growth-rate-saturat } \\
\text { Growth-rate-limiting }\end{array}$ & & & & \\
\hline
\end{tabular}

\section{Field studies}

The surface Chl a concentrations and Sigma-t $(\sigma-t)$ were determined during a ca $90 \mathrm{~km}$ transect from north of the mouth of the York River, seaward past the Chesapeake Light (Fig. 1, upper). The transect crossed the plume between Cape Charles and Cape Henry at the mouth of the Bay. At the frontal interface, the surface salinity and $(\sigma-t)$ increased from 23.82 to $28.21 \%$ and 18.73 to $22.28 \%$, respectively, and $\mathrm{Chl} a$ decreased from 11.4 to $1.5 \mu \mathrm{g} \mathrm{l}^{-1}$ (Fig. 1). At Stns A and $B$ (Table 4 ) on the oceanic side of the front, the water column was well mixed to the bottom (Fig. $1 \mathrm{~A}, \mathrm{~B}$ ): the stratification parameter, $\Delta \sigma-\mathrm{t} / \Delta \mathrm{Z}$ (where $\Delta \sigma$-t was the density difference between the surface and the bottom of depth $\mathrm{Z} \mathrm{m}$ ), was 0.047 to 0.098 (Table 4 ) and the Chl a concentrations were low and uniform throughout the water column (Fig. 1A, B). In contrast, at Stns C and D on the estuarine side of the front, the water column was stratified: the $\Delta \sigma-t / \Delta Z$ (Table 4) and Chl a (Fig. 1) was greater at Stns $C$ and D than at Stns A and B. At Stns C and $\mathrm{D}$, the Chl a was higher above than below the pycnocline (Fig. 1C, D).

The species-specific photosynthetic characteristics and RuBPCase activities of 2 common species of coastal phytoplankton, Ditylum brightwellii and Ceratium lineatum, were measured at Stns A to D. Samples were collected near the surface and bottom at Stns A and B and within the surface mixed layer and below the pycnocline at Stns C and D (Fig. 1A to D). The average irradiance for the mixed layer $\left(I_{M L}\right)$ at all stations was 11 to $18 \%$ of incident (Table 4 ). At Stns $C$ and D, the

Table 4. Physical and hydrographic parameters at the 4 stations where the physiological characteristics of the phytoplankton were measured. $I_{M L}$ : Average irradiance for the mixed layer $\left(I_{M L}=I_{0}\left[\left(1-e^{-k M L}\right) /\left(k_{M L}\right)\right]\right)$ expressed as percent of incident. $I_{0}$ is the incident irradiance. IPYC: Irradiance at the pycnocline expressed as percent of incident. NP: no pycnocline present. Stratification parameter: $\Delta \sigma-t / \Delta Z$

\begin{tabular}{|c|c|c|c|c|}
\hline \multirow[t]{2}{*}{ Parameter } & \multicolumn{4}{|c|}{ Station } \\
\hline & A & $\mathrm{B}$ & $\mathrm{C}$ & $\mathrm{D}$ \\
\hline Position & $\begin{array}{l}36^{\circ} 53.45^{\prime} \mathrm{N} \\
75^{\circ} 41.90^{\prime} \mathrm{W}\end{array}$ & $\begin{array}{l}36^{\circ} 56.35^{\prime} \mathrm{N} \\
75^{\circ} 58.35^{\prime} \mathrm{W}\end{array}$ & $\begin{array}{l}37^{\circ} 10.00^{\prime} \mathrm{N} \\
76^{\circ} 09.32^{\prime} \mathrm{W}\end{array}$ & $\begin{array}{l}37^{\circ} 21.45^{\prime} \mathrm{N} \\
76^{\circ} 04.90^{\prime} \mathrm{W}\end{array}$ \\
\hline Mixed layer (m) & 17 & 15 & 6 & 7 \\
\hline Attenuation coefficient $\left(\mathrm{m}^{-1}\right)$ & 0.51 & 0.51 & 0.94 & 0.94 \\
\hline$I_{M L}(\%)$ & 11 & 13 & 18 & 15 \\
\hline$I_{P Y C}(\%)$ & NP & NP & $<0.1$ & $<0.1$ \\
\hline Stratification parameter & 0.047 & 0.098 & 0.314 & 0.398 \\
\hline
\end{tabular}



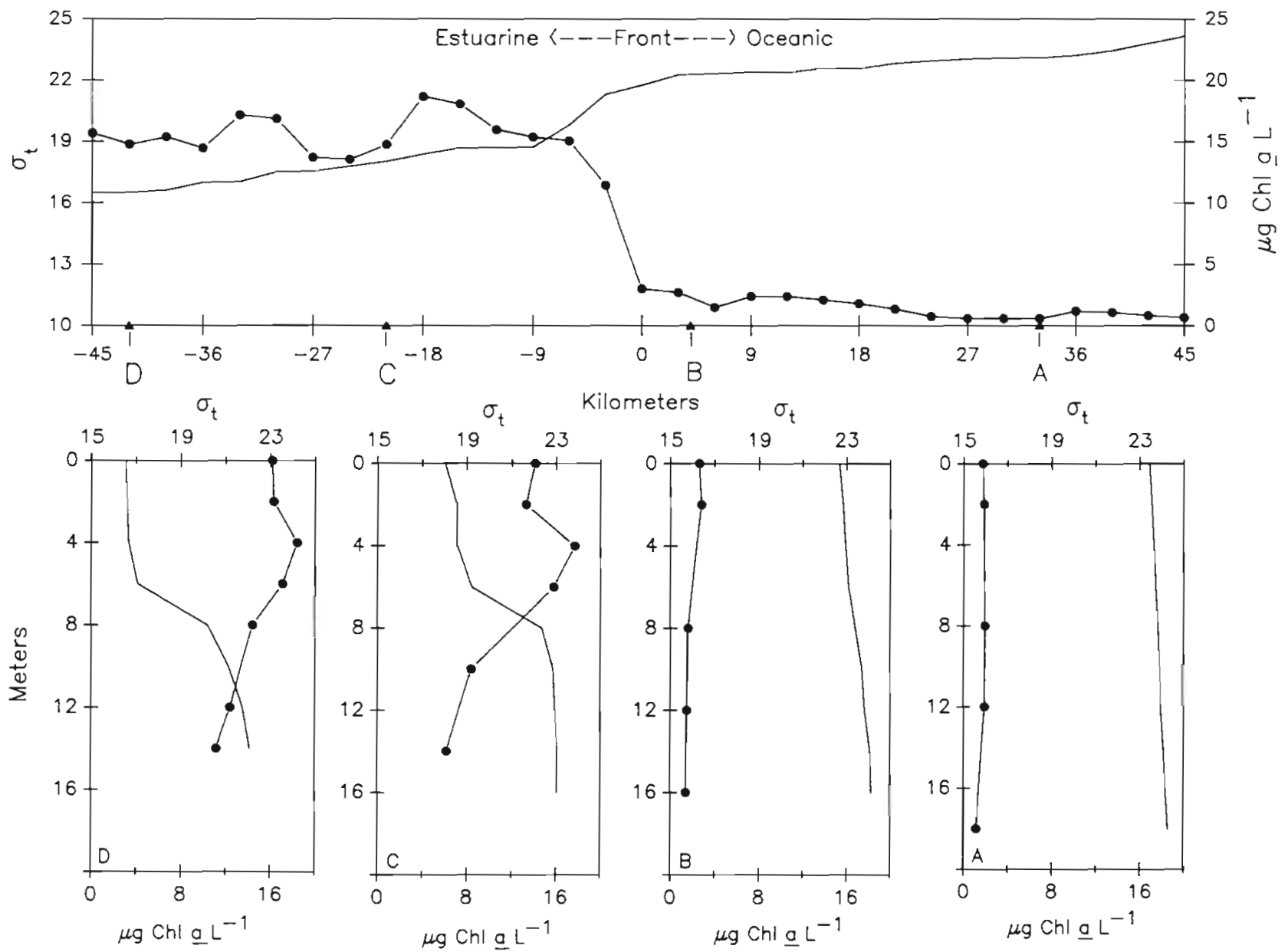

Fig. 1. Upper: Synoptic transect of surface $\sigma-t(-)$ and chlorophyll a $(\bullet)$ across a Chesapeake Bay plume-front during late March 1984. Positions of Stns A to D (reading from right to left) are noted by their respective letters. The location of the frontal intertace is indicated; and the upstream, i.e. the estuarine side of the front, and downstream, i.e. oceanic side of the front, directions were arbitrarily designated as negative and positive distances, respectively. Lower: Vertical profiles of $\sigma$-t ( $\longrightarrow$ ) and chlorophyll a ( $\bullet$ ) at Stns A and B on the oceanic side and Stns C and D on the estuarine side of the Chesapeake Bay plume-front

average irradiance at the 6 to $7 \mathrm{~m}$ pycnocline $\left(\mathrm{I}_{\mathrm{PYC}}\right)$ was $<0.1 \%$ of incident insolation (Table 4 ).

The photosynthetic characteristics of the diatom Ditylum brightwellii collected throughout the water column at Stns $A$ and $B$, and from the surface mixed layer at Stns C and D (Fig. 2) were similar: Pmax and $\alpha$ were ca 180 to $200 \mathrm{pg} \mathrm{C} \mathrm{cell}^{-1} \mathrm{~h}^{-1}$ and 0.59 to $0.69 \mathrm{pg} \mathrm{C}$ cell $^{-1} \mathrm{~h}^{-1}\left(\mu \mathrm{E} \mathrm{m} \mathrm{m}^{-2} \mathrm{~s}^{-1}\right)^{-1}$, respectively. Photosynthesis saturated (Isat) at ca $300 \mu \mathrm{E} \mathrm{m} \mathrm{m}^{-2} \mathrm{~s}^{-1}$ and photoinhibition of photosynthesis was not observed (Fig. 2A to D). When $D$. brightwellii was isolated from below the pycnocline ( 9 to $10 \mathrm{~m}$ ) at Stns $C$ and $D$ (Fig 2C, D), the Pmax and Isat were 2 to 4 times lower and $\alpha$ was $60 \%$ greater $\left[0.98\right.$ to $1.03 \mathrm{pg} \mathrm{C}$ cell $\left.^{-1} \mathrm{~h}^{-1}\left(\mu \mathrm{E} \mathrm{m} \mathrm{m}^{-2} \mathrm{~s}^{-1}\right)^{-1}\right]$ than when collected at Stns A and B or in surface waters of Stns $C$ and D. The spatial and depth-dependent patterns of RuBPCase activity were similar to those of Pmax. Carboxylase activity for $D$. brightwellii collected throughout the water column at Stns $A$ and $B$ and in the surface waters of Stns C and D was 100 to $140 \mathrm{pg} \mathrm{C}$ cell ${ }^{-1} \mathrm{~h}^{-1}$, compared to 30 to $60 \mathrm{pg} \mathrm{C}$ cell ${ }^{-1} \mathrm{~h}^{-1}$ when collected from below the pycnocline at Stns C and D (Fig. $2 \mathrm{a}$ to $\mathrm{d}$ ).

The depth-dependent patterns of photosynthesis and RuBPCase activity of the dinoflagellate Ceratium Lneatum (Fig. 3) were qualitatively similar to those of Ditylum brightwellii (Fig. 2). When C. lineatum was collected from Stns A and B or the surface mixed layer at Stns $C$ and D, Pmax and $\alpha$ were ca 85 to $90 \mathrm{pg} \mathrm{C}$ cell ${ }^{-1}$ $\mathrm{h}^{-1}$ and 0.26 to $0.34 \mathrm{pg} \mathrm{C}$ cell ${ }^{-1} \mathrm{~h}^{-1}\left(\mu \mathrm{E} \mathrm{m} \mathrm{m}^{-2} \mathrm{~s}^{-1}\right)^{-1}$, respectively. Photosynthesis saturated at ca 200 to 250 $\mu \mathrm{E} \mathrm{m}^{-2} \mathrm{~s}^{-1}$ and photoinhibition of photosynthesis was not observed (Fig. 3A to D). However, when C. lineatum was isolated from below the pycnocline at Stns $C$ and $D$ (Fig. 2C, D), Pmax and Isat declined to ca $60 \mathrm{pg} \mathrm{C}$ cell $^{-1}$ $\mathrm{h}^{-1}$ and 80 to $100 \mu \mathrm{E} \mathrm{m}^{-2} \mathrm{~s}^{-1}$, respectively; $\alpha$ increased to 0.73 to $0.76 \mathrm{pgC} \mathrm{Cell}^{-1} \mathrm{~h}^{-1}\left(\mu \mathrm{E} \mathrm{m}^{-2} \mathrm{~s}^{-1}\right)^{-1}$ and $C$ uptake was photoinhibited above ca $300 \mu E \mathrm{~m}^{-2} \mathrm{~s}^{-1}$. The 

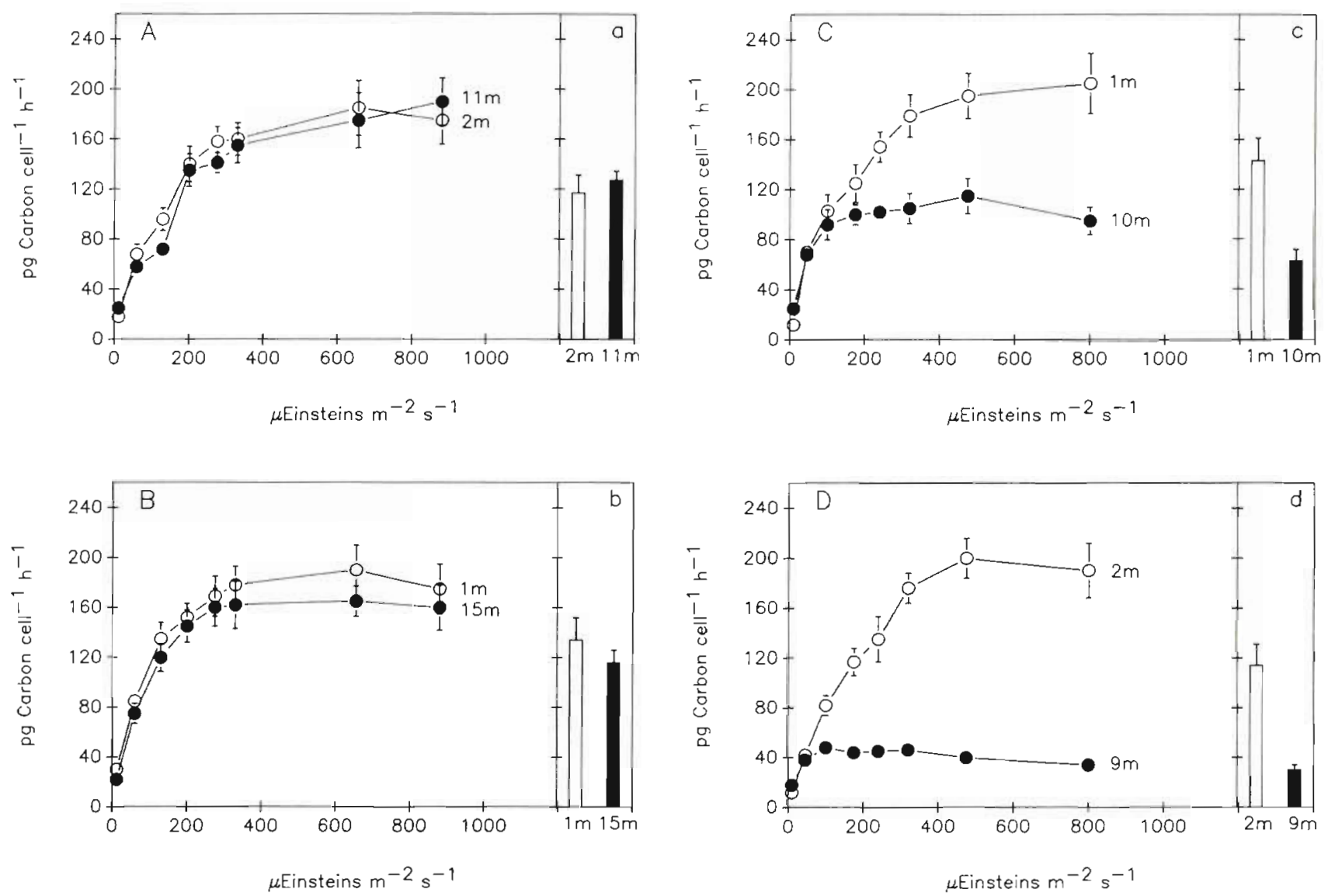

Fig. 2. Ditylum brightwellii. Photosynthesis-irradiance relationship (left panels, A to D) and ribulose 1,5-bisphosphate carboxylase activity (right panels, a to d) of isolates from near the surface (open symbols or bars) or the bottom (filled symbols or bars) at Stns A $(A$ and $a)$ and $B(B$ and $b$ ) on the oceanic side, and Stns C ( $C$ and $c)$ and D (D and d) on the estuarine sides of the front. Units for Pmax and RuBPCase are pg C cell ${ }^{-1} \mathrm{~h}^{-1}$; error bars represent standard deviation of mean

patterns of RuBPCase activity and Pmax were similar (Fig. 3a to d). RuBPCase activity for C. lineatum collected at Stns $A$ and $B$ and in the surface waters of Stns $C$ and $\mathrm{D}$ were 40 to $60 \mathrm{pg} \mathrm{C}$ cell ${ }^{-1} \mathrm{~h}^{-1}$, compared to 25 to $30 \mathrm{pg} \mathrm{C}$ cell $^{-1} \mathrm{~h}^{-1}$ when collected from below the pycnocline at Stns C and D (Fig. 3a to d).

The relationships between Pmax and RuBPCase activity were significant $(\mathrm{p}=0.01)$ and linear for Ditylum brightwellii and Ceratium lineatum (Table 2). When the coordinate pairs of Pmax and RuBPCase for the 2 species collected at all stations and depths were combined, the relationship (Eqn 2) between Pmax and RuBPCase was linear and significant $(p=0.01)$ :

$$
\begin{gathered}
\text { RuBPCase }=-8.249( \pm 16.288)+0.743 \cdot \operatorname{Pmax}( \pm 0.136) ; \\
\mathrm{r}^{2}=0.906
\end{gathered}
$$

The values in parentheses are the $95 \%$ confidence intervals ( $n=48$ ). The regression coefficients for the individual species (Table 2) and for the combined data were not significantly ( $p=0.05$ ) different and the ordinal intercept did not differ significantly $(\mathrm{p}=0.05)$ from zero.

\section{DISCUSSION}

RuBPCase catalyzes the carboxylation of 1 molecule of RuBP to 2 of 3-phosphoglycerate (PG). Since the maximum rate of inorganic $C$ reduction is set by concentration and activity of this enzyme, the relationship between photosynthesis and RuBPCase activity should be linear when photosynthesis is light-saturated (Bjorkman 1981). However, there is no physiological basis to expect a relationship between $\mathrm{C}$ uptake and RuBPCase when photosynthesis is irradiance-limited. In this study, the relationship between Pmax and RuBPCase was linear and significant (Eqns 1 and 2). For example, all the coordinate pairs of Pmax and RuBPCase from the laboratory and field experiments (Fig. 4) were fit to a single linear regression (Eqn 3).

RuBPCase $=-1.686( \pm 7.875)+0.677 \operatorname{Pmax}( \pm 0.043) ;$

$$
r^{2}=0.872 \text {. }
$$

The values in parentheses are the $95 \%$ confidence intervals $(n=84)$. Since RuBPCase was highly corre- 

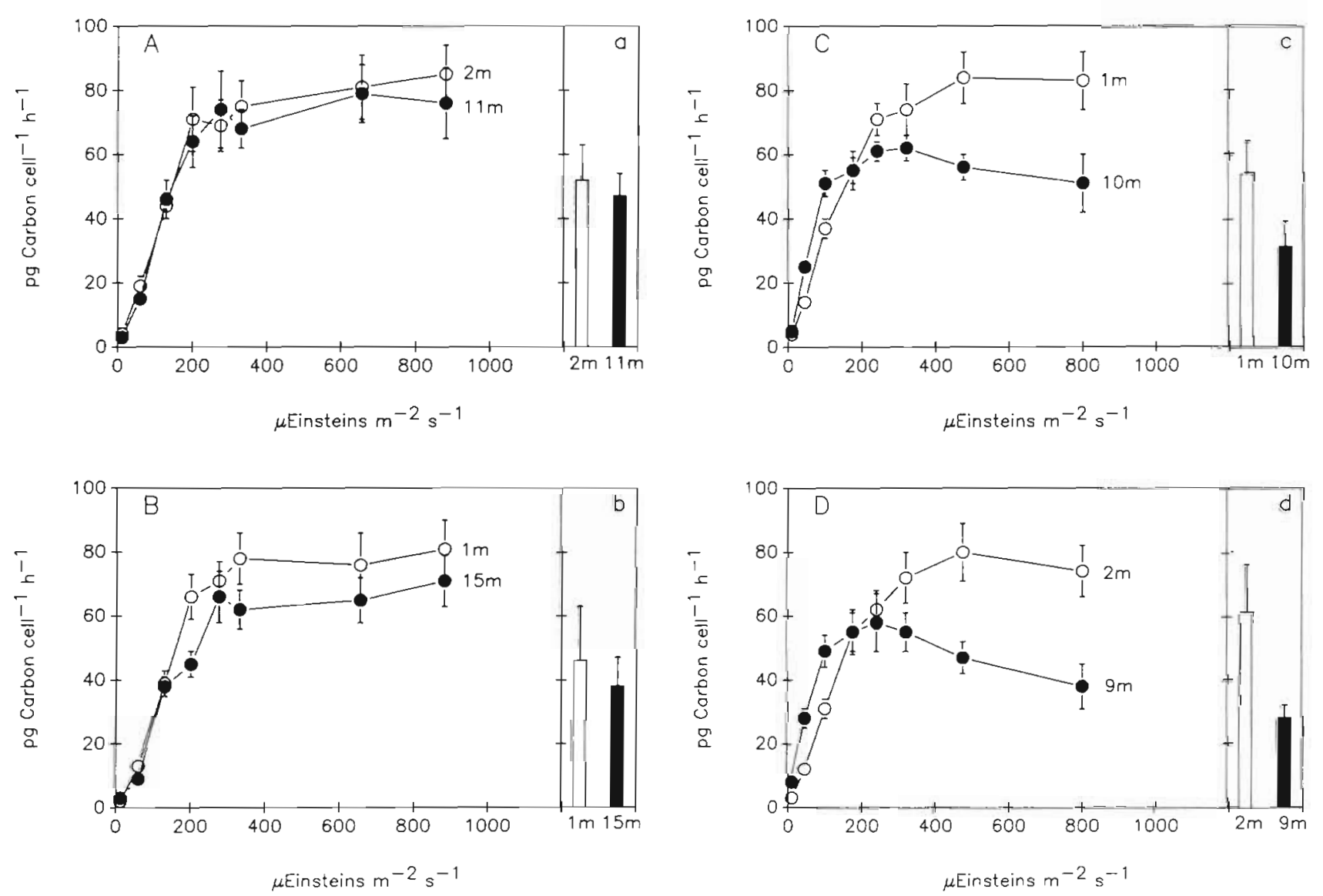

Fig. 3. Ceratium lineatum. Photosynthesis-irradiance relationship (left panels, A to D) and ribulose 1,5-bisphosphate carboxylase activity (right panels, a to $d$ ) of isolates from near the surface (open symbols or bars) or the bottom (filled symbols or bars) at Stns $A$ ( $A$ and $a)$ and $B(B$ and $b$ ) on the oceanic side, and Stns $C$ ( $C$ and $C$ ) and $D$ ( $D$ and d) on the estuarine sides of the front. Units for Pmax and RuBPCase are pg C cell ${ }^{-1} \mathrm{~h}^{-1}$; error bars represent standard deviation of mean

lated with Pmax, but not with photosynthetic performance, i.e. the rate of photosynthesis at the growth or ambient irradiances, the activity of this enzyme cannot be used to estimate the in situ rate of $C$ uptake by phytoplankton (also see Glover \& Morris 1979).

Few studies have concurrently measured Pmax and RuBPCase activities. In those which have, significant linear relationships between Pmax and RuBPCase were reported for terrestrial plants $\left(\mathrm{r}^{2}=0.92\right.$; Bjorkman 1981), for a spring phytoplankton bloom in Bedford Basin, Nova Scotia ( $\mathrm{r}^{2}=0.82$; Smith et al. 1983) and for exponentially growing phytoplankton cultures $\left(\mathrm{r}^{2}=\right.$ 0.62; Glover \& Morris 1979). However, significant relationships were not observed for stationary phase cultures, a phytoplankton population in the Gulf of Maine, and Synechococcus spp. from the Northwest Atlantic Ocean (Glover \& Morris 1979, Prezelin et al. 1987). The temporal and spatial variability in the relationship between Pmax and RuBPCase activity reported in previous studies of natural populations may, in part, reflect the species-specific differences in the physiological characteristics of co-occurring phytoplankton. Such differences could obscure significant physiological trends. However, the relationships among physiological characteristics of phytoplankton from natural populations can be detected by measuring the rates of C uptake (Rivkin \& Seliger 1981, Rivkin \& Putt 1987), polymer synthesis (Rivkin 1985) and cell division (Rivkin \& Voytek 1986) or the activity of carboxylating enzymes for individual species.

The mean RuBPCase:Pmax ratios during these laboratory and field experiments were 0.61 (range 0.47 to 0.70 ) and 0.74 (range 0.52 to 0.81 ), respectively In previous studies, the RuBPCase: Pmax ratios were 0.14 to 0.75 for cultures and natural populations (Beardall \& Morris 1978, Glover \& Morris 1979, Rivkin et al. 1982. Rivkin \& Lessard 1986, Mortain-Bertrand et al. 1987. Prezelin et al. 1987): ratios of near 1 have occasionally been reported (Holdsworth \& Colebrook 1976, Hobson et al. 1985). The reasons for the large variation in ratios are unclear and may reflect non-optimal assay conditions, incomplete activation of the enzyme, inhibitors in 


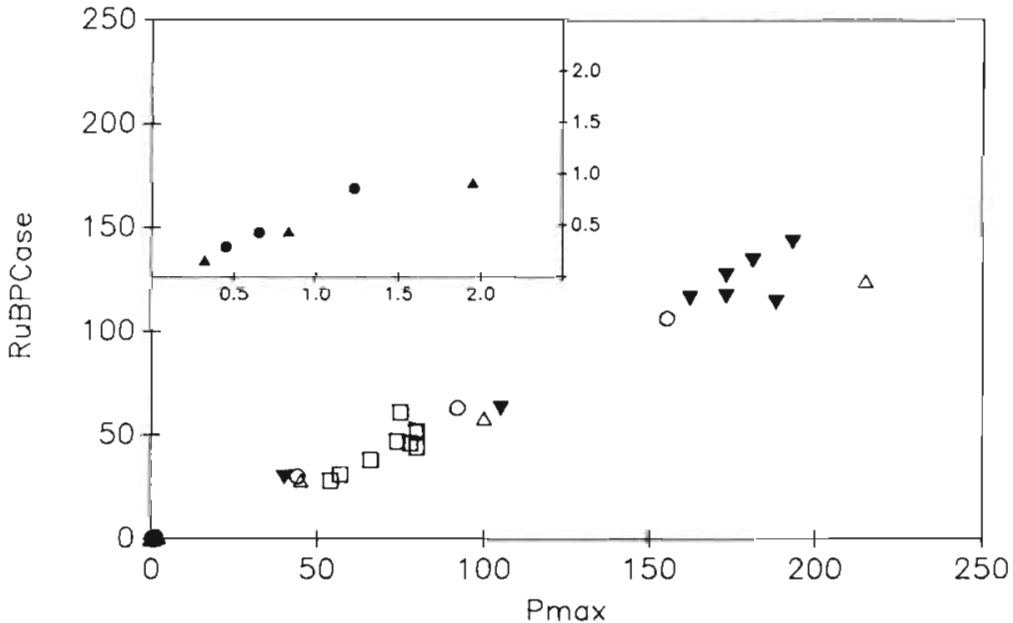

Fig. 4. Linear relationship between paired measurements of photosynthetic capacity (Pmax; pg C cell ${ }^{-1} \mathrm{~h}^{-1}$ ) and ribulose 1,5-bisphosphate carboxylase (RuBPCase; pg C cell ${ }^{-1} \mathrm{~h}^{-1}$ ) activity for phytoplankton cultured at growth-limiting and saturating irradiances and for phytoplankton isolated from high and low irradiances environments at the mouth of the Chesapeake Bay, Laboratory cultures: Skeletonema costatum (•), Ditylum brightwellii $(\Delta)$, Dunaliella tertiolecta $(\mathbf{\Delta})$ and Protogonyaulax tamarensis (o). Isolated from natural populations: Ditylum brightwellii ( $\mathbf{\nabla})$ and Ceratium lineatum ( $\square$ ). Inset shows expanded scalés of Pmax and RuBPCase activity for S. costatum and $D$. tertiolecta. Each point is mean of 3 to 4 replicate samples the assay mixture or the assimilation of ${ }^{14} \mathrm{C}$ by pathways other than the Calvin cycle (Jensen \& Sicher 1978, Glover \& Morris 1979, Morris 1981). Although C incorporation by the $\beta$-carboxylating enzymes PEPCase or PEPCKase may at times be significant (Mukerji \& Morris 1976, Mukerji et al. 1978, Glover \& Morris 1979, Smith et al, 1983, Prezelin et al, 1987), their activities are typically low $(<10 \%)$ relative to RuBPCase (Li \& Morris 1982, Li et al. 1984, Descolas-Gros \& Fontugne 1985, Smith et al. 1985, Mortain-Bertrand 1988). In this study, PEPCase and PEPCKase were not measured. However, the linear relationship between RuBPCase and photosynthetic capacity and the relatively high RuBPCase: Pmax ratio suggest the activity of the $\beta$-carboxylating enzymes was either low or a constant proportion of Pmax.

Field studies were carried out in late March at a Chesapeake Bay plume front (Boicourt et al. 1987). The density structure across the plume varies with river flow, tidal phase and the angle of the transect across the front (Garvine \& Monk 1974, Boicourt \& Hacker 1976, Boicourt et al. 1987, Boicourt pers. comm.). Although the lateral dimensions of the plume were not determined, the density structure presented in the upper panel of Fig. 1 probably represents an oblique transect (Boicourt pers. comm.). Phytoplankton entrained at the frontal interface in the inflow of higher salinity seawater from the continental shelf would be transported upstream beneath a strong pycnocline in the reverse Ekman flow (Boicourt \& Hacker 1976, Tyler \& Seliger 1978, 1981, Boicourt 1982). These phytoplankton are thus advected from a region of relatively high irradiances on the unstratified side of the front at Stns $\mathrm{A}$ and $\mathrm{B}$, i.e. $\mathrm{I}_{\mathrm{ML}}=12 \%$, to low irradiances below the pycnocline on the stratified side of the front at Stns $C$ and D, i.e. $I_{P Y C}<0.1 \%$. Phytoplankton collected upstream of the frontal interface would be at low irradiances for increasing lengths of time the greater the distance upstream. Consequently, they should exhibit characteristics of increased shade adaptations compared with the same species in the surface mixed layer or at the mouth of the Chesapeake Bay. For example, the light-saturated rates of photosynthesis are usually higher and $\alpha$ cell $^{-1}$ is usually lower for phytoplankton which are collected at high irradiances in the surface mixed layer than when collected from low light environments (Harris 1978, Falkowski 1980, 1983, Rivkin et al. 1982, Richardson et al. 1983, Rivkin \& Voytek 1985, Harding \& Coats 1988 and others).

In this study, the photosynthetic characteristics and RuBPCase activity of Ditylum brightwellii and Ceratium lineatum were clearly related to the photic regime. The photosynthetic parameters and carboxylase activities of these 2 species collected throughout the water column at Stns $A$ and $B$ and near the surface at Stns $C$ and D were similar. Although the diffuse attenuation coefficient was significantly lower on the oceanic than estuarine side of the front (Table 4), the mixed layer was ca 2 to 3 times deeper at Stns A and B than at $C$ and $D$, thus the average mixed layer irradiance was similar at all stations (Table 4). In contrast, the irradiance at the pycnocline at Stns C and D was $<0.1 \%$ of incident. At Stns $C$ and $D$, the density stratification prevented the phytoplankton collected below the pycnocline (at 9 to $10 \mathrm{~m}$ ) from mixing into the comparatively well-illuminated surface waters. As a result, the Pmax and RuBPCase activity of $D$. brightwellii and $C$. lineatum from collected from below the pycnocline at the stratified stations were smaller and $\alpha$ was larger than for the same species collected either from the surface mixed layer, or throughout the water column at the unstratified stations. The decrease in photosynthetic capacity and carboxylase activity and increase in $\alpha$ reflects photoadaptation to the low light environment below the pycnocline. A similar pattern of 
photoadaptation was observed for the dinoflagellate Prorocentrum mariae-lebouriae during its vernal subpycnocline transport from the southern to the northern Chesapeake Bay (Tyler \& Seliger 1978, 1981, Harding 1988, Harding \& Coats 1988).

The rates of vertical mixing within the euphotic zone can be estimated by concurrently measuring the vertical distribution and kinetics of adaptation of several different photoadaptive parameters (Falkowski 1983, Lewis et al. 1984a, Cullen \& Lewis 1988). Determining photosynthetic capacity or $\alpha$ requires measuring the rates of photosynthesis during incubations at a range of irradiances and choosing the appropriate equation for calculating the P-I curve parameters. Enclosing samples, even during brief incubations, may induce experimental artifacts. Hence, the photosynthetic parameters calculated during these incubations may not accurately represent the characteristics of the phytoplankton in situ. This study showed that changes in Pmax correlated with those of RuBPCase activity and the relationship between RuBPCase activity and Pmax for light limited and saturated phytoplankton in laboratory cultures and for individual species of net-plankton isolated from a variety of photic regimes was linear and significant (Eqns 1 to 3 ). Therefore, cell-specific RuBPCase measured for phytoplankton collected at discrete depths may be a useful photoadaptive parameter and could be used to evaluate photoadaptations without the need for detailed P-I curves. The kinetics of adaptation of phytoplankton to a new photic regime and the interaction of photoadaptive processes of net phytoplankton with the rates of vertical mixing are currently being examined using cell-specific assays.

Acknowledgements. I thank the captain and crew of the RV 'Cape Hatteras' for their assistance, M. R. Anderson, D. E. Gustafson and P. M. Glibert for helpful comments on early drafts of this manuscript, and Ms K. M. Smith for the graphics. This research was supported by the National Science Foundation, Division of Ocean Sciences Grant Nos. OCE 83-00739, OCE 83-14707 and OCE 85-16214. University of Maryland, Center for Environmental and Estuarine Studies Contribution No. 2093.

\section{LITERATURE CITED}

Appleby, G., Colbeck, J., Holdsworth, E. S., Wadman, H (1980). $\beta$-carboxylation enzymes in marine phytoplankton and isolation and purification of pyruvate carboxylase from Amphidinium carterae (Dinophyceae). J. Phycol. 16 $290-295$

Akazawa, T., Takabe, T., Kobayashi, H. (1984). Molecular evolution of ribulose 1,5-bisphosphate carboxylase/oxygenase (RuBisCO). Trends biochem. Sciences 9: 380-383

Beardall, J., Morris, I. (1978). The concept of light intensity adaptation in marine phytoplankton: some experiments with Phaeodactylum tricomutum. Mar Biol. 37: 377-387
Beardall, J., Mukerji, D., Glover, H. E., Morns, I. (1976). The path of carbon in photosynthesis by marine phytoplankton. J. Phycol. 4: 409-417

Bjorkman, O. (1981). Responses to different quantum flux densities, In: Lange, O. L., Nobel, P. S., Osmond, C. B., Ziegler, H. (eds.) Physiological plant ecology. SpringerVerlag, New York, p. 57-107

Boicourt, W. C. (1982). Estuarine larval retention mechanisms on two scales. In: Kennedy, V. S. (ed.) Estuarine comparisons. Academic Press, New York, p. 4.45-457

Boicourt, W. C., Chao, S.-Y., Ducklow, H. W., Glibert, P. M. Malone, T. C., Roman, M. R., Sanford, L. P., Fuhrman, J A., Garside, C., Garvine, R. W. (1987). Physics and microbial ecology of a buoyant estuarine plume on the continental shelf. EOS Trans. Am. geophys. Un. 68: 666-668

Boicourt, W C., Hacker, P. W. (1976). Circulation on the Atlantic continental shelf of the United State, Cape May to Cape Hatteras. Mém. Soc. r. Sci. Liège (Ser. 6) 10: 187-200

Cullen, J. J., Lewis, M. R. (1988). The kinetics of algal photoadaptation in the context of vertical mixing. J. Plankton Res. 10: 1039-1063

Descolas-Gros, C., Billy, G. (1987). Temperature adaptation of RuBP carboxylase: kinetic properties in a marine Antarctic diatom. J. exp. mar. Biol. Ecol. 108: 147-158

Descolas-Gros, C., Fontugne, M. R. (1985). Carbon fixation in marine phytoplankton: carboxylase activities and stable carbon-isotope ratios; physiological and paleoclimatological aspects. Mar. Biol. 87: 1-6

Estep, M. F., Tabita, F. R., Van Baalen, C. (1978). Purification of ribulose 1,5-bisphosphate carboxylase and carbon isotope fractionation by whole cells and carboxylase from Cylindrotheca sp. (Bacillariophyceae). J. Phycol. 14: 183-188

Falkowski, P. G. (1980). Light-shade adaptation in marine phytoplankton. In: Falkowski, P. G. (ed.) Primary productivity in the sea. Plenum Press, New York, p. 99-119

Falkowski, P. G. (1983). Light-shade adaptation and vertical mixing of marine phytoplankton: a comparative study. J. mar Res. 41: 215-237

Garvine, R. W., Monk, J. D. (1974). Frontal structure of a river plume. J. geophys. Res. 79: 2251-2259

Glover, H. E., Beardall, J., Morris, I. (1975). Effects of environmental factors on photosynthetic patterns in Phaeodactylum tricornutum (Bacillariophyceae) I. Effects of nitrogen deficiency and light intensity. J. Phycol. 11: $424-429$

Glover, H. E, Morris, I. (1979). Photosynthetic carboxylating enzymes in marine phytoplankton. Limnol. Oceanogr. 24 $510-519$

Guillard, R. R. L., Ryther, J. H. (1962). Studies of marine planktonic diatoms. I. Cyclotella nana Hustedt and Detonula confervacea (Cleve.) Gran. Can. J. Microbiol. 8: $229-239$

Guy, R. D., Vanlerberghe, C., Turpin, D. H. (1989). Significance of phosphoenolpyruvate carboxylase during ammonium assimilation. Plant Physiol. 89: 1150-1157

Harding, L. W. (1988). The time-course of photoadaptation of Prorocentrum mariae-lebouriae (Dinophyceae). J. Phycol. 24: $274-288$

Harding, L. W. Coats, D. W. (1988). Photosynthetic physiology of Prorocentrum mariae-lebouriae (Dinophyceae) during its subpycnocline transport in Chesapeake Bay. J. Phycol. 24: 77-89

Harris, G. P. (1978). Photosynthesis, productivity and growth. The physiological ecology of phytoplankton. Arch. Hydrobiol. (Beih. Ergeb. Limnol.) 10: 1-171

Harris, G. P. (1980). Spatial and temporal scales in phyto- 
plankton ecology. Mechanisms, methods, models and management. Can. J. Fish. aquat. Sciences 37: 877-900

Hellebust, J. A., Terborgh, J. (1967). Effects of environmental conditions on the rate of photosynthesis and some photosynthetic enzymes in Dunaliella tertiolecta Butcher Limnol. Oceanogr. 12: 559-567

Hobson, L. A., Morris, W. J., Guest, K. P. (1985). Varying photoperiod, ribulose 1,5-bisphosphate carboxylase/oxygenase and $\mathrm{CO}_{2}$ uptake in Thalassiosira fluviatilis (Bacillariophyceae). Plant Physiol. 79: 833-837

Holdsworth, E. S., Bruck, K. (1977). Enzymes concerned with $\beta$-carboxylation in marine phytoplankter. Purification and properties of phosphoenolpyruvate carboxykinase. Archs Biochem. Biophys. 182: 87-94

Holdsworth, E. S., Colbeck, J. (1976). The pattern of carbon fixation in the marine unicellular algae Phaeodactylum tricornutum. Mar. Biol. 38: 189-199

Holligan, P. M., Harris, R. P., Newell, R. C., Harbour, D. S., Head, R. N., Linley, E. A. S., Lucas, M. I., Tranter, P. G. R., Weekley, C. M. (1984). Vertical distribution and partitioning of organic carbon in mixed, frontal and stratified waters of the English Channel. Mar. Ecol. Prog. Ser 14: $111-127$

Jassby, A. D., Platt, T. (1976). Mathematical formulation of the relationship between photosynthesis and light for phytoplankton. Limnol. Oceanogr. 21: 540-547

Jensen, R. G., Sicher, R. C. (1978). Regulation of ribulose 1,5bisphosphate carboxylase in the chloroplast. In: Siegelman, H. W., Hind, G. (eds.) Photosynthetic carbon assimilation. Plenum Press, New York, p. 95-122

Kobza, J., Seemann, J. R. (1988). Mechanisms for the light regulation of ribulose 1,5-bisphosphate carboxylase activity and photosynthesis in intact leaves. Proc. natn. Acad. Sci. U.S.A. 85: 3815-3819

Lewis, M. R., Cullen, J. J., Platt, T (1984a). Relations between vertical mixing and photoadaptations of phytoplankton: similarity criteria. Mar. Ecol. Prog. Ser. 15: 141-149

Lewis, M. R., Horne, E. P. W., Cullen, J. J., Oakey, N. S., Platt, T. (1984b). Turbulent motion may control phytoplankton photosynthesis in the upper ocean. Nature, Lond. 311: $49-50$

Li, W. K. W., Morris, I. (1982). Temperature adaptation in Phaeodactylum tricornutum Bohlin: photosynthetic rate compensation and capacity. J. exp. mar. Biol. Ecol. 58: $135-150$

Li, W. K. W., Smith, J. C., Platt, T. (1984). Temperature response of photosynthetic capacity and carboxylase activity in Arctic marine phytoplankton. Mar Ecol. Prog. Ser. 17: $237-243$

Lorimer, G. H. (1981). The carboxylation and oxygenation of ribulose 1,5-bisphosphate: the primary events in photosynthesis and photorespiration. A. Rev. Pl. Physiol. 32: 349-383

Miziorko, H. M., Lorimer, G. H. (1983). Ribulose 1,5-bisphosphate carboxylase-oxygenase. A. Rev. Biochem. 52: 507-535

Morris, I. (1981). Photosynthesis products, physiological state and phytoplankton growth. Can. Bull. Fish. aquat. Sciences 210: 83-102

Mortain-Bertrand, A. (1988). Photosynthetic metabolism of an Antarctic diatom and its physiological responses to fluctuations in light. Polar Biol. 9: 53-60

Mortain-Bertrand, A., Descolas-Gros, C., Jupin, H. (1987). Stimulating effect of light-to-dark transitions on carbon assimilation by a marine diatom. J. exp. mar. Biol. Ecol. 112: $11-26$

Mukerji, D., Glover, H. E., Morris, I. (1978). Diversity in the mechanisms of carbon dioxide fixation in Dunaliella tertiolecta (Chlorophyceae). J. Phycol. 14: 137-142

Mukerji, D., Morris, I. (1976). Photosynthetic carboxylating enzymes in Phaeodactylum tricornutum. Assay methods and properties. Mar Biol. 36: 199-206

Newman, S. M., Cattolico, R. A. (1987). Structural, functional and evolutionary analysis of ribulose-1,5-bisphosphate carboxylase from the chromophytic alga Olithodiscus luteus. Plant Physiol. 84: 483-490

Pingree, R. D., Pugh, P. R., Holligan, P. M., Forster, G. R. (1975). Summer phytoplankton blooms and red tides along tidal fronts in the approaches to the English Channel. Nature, Lond. 258: 672-677

Plumley, F. H., Kirshman, D. L., Hodson, R. E., Schmidt, G. W. (1986). Ribulose bisphosphate carboxylase from three chlorophyll c-containing algae. Physical and immunological characterizations. Plant Physiol. 80: 685-691

Prezelin, B. B., Glover, H. E., Campbell, L. (1987). Effects of light intensity and nutrient availability on diel patterns of cell metabolism and growth in populations of Synechococcus spp. Mar. Biol. 95: 469-480

Richardson, K., Beardall, J., Raven, J. A. (1983). Adaptation of unicellular algae to irradiance: an analysis of strategies. New Phytol. 93: 157-191

Rivkin, R. B. (1985). Carbon-14 labelling patterns of individual marine phytoplankton from natural populations. Mar. Biol. 89: $135-142$

Rivkin, R. B., Lessard, E. J. (1986). Photoadaptation of photosynthetic carbon uptake by solitary Radiolaria: comparisons with free living phytoplankton. Deep Sea Res. 33: $1025-1038$

Rivkin, R. B., Putt, M. (1987). Photosynthesis and cell division by antarctic microalgae: comparison of benthic, planktonic and ice algae. J. Phycol. 23: 223-229

Rivkin, R. B., Seliger, H. H. (1981). Liquid scintillation counting for ${ }^{14} \mathrm{C}$ uptake of single algal cells isolated from natural samples. Limnol. Oceanogr. 26: 780-785

Rivkin, R. B., Seliger, H. H., Swift, E., Biggley, W. H. (1982). Light-shade adaptation by the oceanic dinoflagellates Pyrocystis noctiluca and $P$. fusiformis Mar Biol. 68 : $181-191$

Rivkin, R. B., Voytek, M. A. (1985). Photoadaptations of photosynthesis by dinoflagellates from natural populations: a species approach. In: Anderson, D. M., White, A., Baden, $M$. (eds.) Third international conference on toxic dinoflagellates. Elsevier Press, New York, p. 97-102

Rivkin, R. B., Voytek, M. A. (1986). Cell division rates of eucaryotic algae measured by DNA synthesis: coincident measurement of photosynthesis and cell division of individual species of phytoplankton from natural populations. J. Phycol. 22: 199-205

Senger, H., Fleischhacker, P. (1978). Adaptations of the photosynthetic apparatus of Scenedesmus obliquus to weak and strong light. I. Differences in pigment, photosynthetic capacity, quantum yield and dark reactions. Physiologia Pl. 43: 35-42

Smith, J. C., Platt, T. (1985). Temperature responses of ribulose bisphosphate carboxylase and photosynthetic capacity in arctic and tropical phytoplankton. Mar. Ecol. Prog. Ser. 25: 31-37

Smith, J. C., Platt, T., Harrison, W. G. (1983). Photoadaptation of carboxylating enzymes and photosynthesis during a spring bloom. Prog. Oceanogr, 12: 425-459

Smith, J. C., Platt, T., Li, W. K. W., Horne, E. P. W., Harrison, W. G., Subba Rao, D. V., Irwin, B. D. (1985). Arctic marine photoautotrophic picoplankton. Mar. Ecol Prog. Ser. 20: $207-220$ 
Tyler, M. A., Seliger, H. H. (1978). Annual subsurface transport of a red tide dinoflagellate to its bloom area: water circulation patterns and organism distributions in the Chesapeake Bay. Limnol. Oceanogr. 23: 227-246

Tyler, M. A., Seliger, H. H. (1981). Selection for a red tide

This article was submitted to the editor organism: physiological responses to the physical environment. Limnol. Oceanogr 26: 310-324

Yeoh, H. H., Badger, M. R., Watson, L. (1981). Variation in the kinetic properties of ribulose-1,5-bisphosphate carboxylase among plants. Plant Physiol. 67: 1151-1155

Manuscript first received: August 22, 1989

Revised version accepted: December 27, 1989 